\title{
Survey of leaf-cutting ant species in native vegetation and monocultures in the State of Goiás, Brazil
}

\section{Levantamento de espécies de formigas cortadeiras em vegetação nativa e monoculturas no estado de Goiás, Brasil}

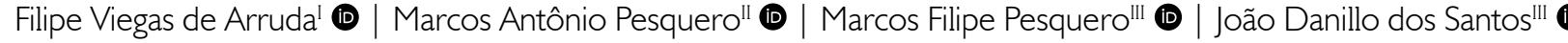 \\ 'Universidade Estadual de Goiás. Programa de Pós-Graduação em Recursos Naturais do Cerrado. Anápolis, Goiás, Brasil \\ "Universidade Estadual de Goiás. Morrinhos, Goiás, Brasil \\ "'Universidade Federal do Tocantins. Porto Nacional, Tocantins, Brasil
}

\begin{abstract}
Leaf-cutting ants are distributed exclusively in the Americas. For this study, we sampled different areas of native vegetation and monocultures to survey the leaf-cutting ants that occur in the State of Goiás, and to what environments they are associated. We recorded six species of leaf-cutting ants: Atta sexdens, Atta laevigata, Acromyrmex subterraneus, Acromyrmex disciger, Acromyrmex ambiguus, and Acromyrmex hispidus. The last four were registered for the first time for the State of Goiás.

Keywords: Savanna. Colony density. Agriculture. Diversity.

Resumo: As formigas cortadeiras apresentam distribuição exclusiva nas Américas. Durante a realização do presente estudo, foram amostradas diferentes áreas de vegetação nativa e de monoculturas, com o intuito de fazer um levantamento das espécies de formigas cortadeiras que ocorrem em Goiás e sobre quais são os ambientes aos quais elas estão associadas. Durante o presente estudo, foram registradas seis espécies de formigas cortadeiras: Atta sexdens, Atta laevigata, Acromyrmex subterraneus, Acromyrmex disciger, Acromyrmex hispidus e Acromyrmex ambiguus, sendo que as últimas quatro foram registradas pela primeira vez para o estado de Goiás.
\end{abstract}

Palavras-chave: Savana. Densidade de colônias. Agricultura. Diversidade.

ARRUDA, F. V., M. A. PESQUERO, M. F. PESQUERO \& J. D. SANTOS, 2020. Survey of leaf-cutting ant species in native vegetation and monocultures in the State of Goiás, Brazil. Boletim do Museu Paraense Emílio Goeldi. Ciências Naturais 15(1): 237-241. DOI: http:// doi.org/10.46357/bcnaturais.v15i1.237.

Autor para correspondência: Filipe Viegas de Arruda. Universidade Estadual de Goiás. Programa de Pós-Graduação em Recursos Naturais do Cerrado. Br 153 n॰ 3.105 - Fazenda Barreiro do Meio, - Anápolis, GO, Brasil. Caixa Postal: 459 (filipeeco@gmail.com).

Recebido em 18/12/2019

Aprovado em 17/03/2020

Responsabilidade editorial: Rony Peterson Santos Almeida 
The ants of genus Atta (Fabricius, 1804) and Acromyrmex (Mayr, 1865) are widely distributed in the Americas (Hölldobler \& Wilson, 1990). They represent together 77 species, 62 species of genus Acromyrmex and 17 of genus Atta (Antweb, 2020). They are known for living in association with the symbiotic fungus Leucoagaricus gongylophorus (Singer 1986), which feeds on fresh vegetable fragments provided by the ants. These ants are considered severe pests, as they defoliate plantations of economic importance, such as eucalyptus and pasture (Zanetti et al., 2000; Della Lucia, 2003; Santos et al., 2019). Currently, the control is performed mainly by using chemical products through baiting or thermal fogging (Oliveira et al., 2011) and researchers have been seeking more efficient ways to control these pests. Studies have shown that the population density of leaf-cutting ants tends to increase in fragmented habitats and monoculture areas (Fowler, 1983; Vasconcelos \& Cherrett, 1995). This population increase occurs mainly due to the lower number of predators in anthropized environments (Rao, 2000; Pesquero et al., 2010; Barrera et al., 2017). Thus, occurrence data of colonies are necessary for a better understanding of the species distribution in native and monoculture environments. This study aimed to survey the species of leaf-cutting ants in native vegetation and monoculture environments in the State of Goiás. Data were collected between September 2005 and July 2006. Samplings were performed by active search in different monoculture areas (soybean, Eucalyptus sp., and pasture of Brachiaria sp.; all treated for at least five years with granulated baits with sulfluramid by the owners) and native vegetation (riparian forest, open shrub savanna 'campo sujo', and grasslands 'campo limpo') in the municipalities of Pirenópolis (1551' S, $48^{\circ} 57^{\prime}$ W), Silvânia (16 40' S, $48^{\circ} 36^{\prime}$ W), and Morrinhos ( $17^{\circ} 45^{\prime}$ S, $49^{\circ} 10^{\prime} \mathrm{W}$ ) in the State of Goiás (Oliveira-Filho \& Ratter, 2002). The sampling period for each area took between four and seven days and this difference in time occurred due to the size difference of the sampled areas. The non-parametric Mann-Whitney $U$ test was used to compare species density in native vegetation and monoculture environments. The species were identified through a dichotomous key (Fowler et al., 1993) and deposited in the entomological collection at the Ecology Laboratory of the Universidade Estadual de Goiás - Campus Morrinhos.

Six species of leaf-cutting ants were recorded in the sampled environments: Atta sexdens (Linnaeus, 1758); Atta laevigata (Smith, 1858); Acromyrmex subterraneus (Forel, 1893); Acromyrmex disciger (Mayr, 1887); Acromyrmex hispidus (Santschi, 1925); Acromyrmex ambiguus (Emery, 1888) (Table 1). Ac. subterraneus, Ac. disciger, Ac. hispidus, and $A c$. ambiguus were registered for the first time in Goiás (Figure 1) (Rando \& Forti, 2005; Delabie et al., 2011; Antweb, 2020). All four Acromyrmex species have been recorded in neighboring States, where Ac. subterraneus had closest records in the States of Mato Grosso, Minas Gerais, and Bahia. Ac. disciger had the closest record in the State of Minas Gerais, while Ac. hispidus and Ac. ambiguus had the closest records in the States of Bahia and Minas Gerais (Antmaps, 2020). The species were compared to the environment where they were recorded, the size of sampled areas, and the number of colonies recorded in each area (Table 1). We found no significant difference between species density in native vegetation and monoculture environments (native vegetation: median $=0.61$ and monoculture: median $=$ 0.43, $U=6, P=0.56$ ) (Figure 2).

The occurrence of the genus Atta was associated with land banks deposited on the sides of roads by leveling machines. The roads directly affect the establishment of new Atta colonies, as well as their dynamics (Vasconcelos et al., 2006). Physical and chemical characteristics of soils, such as porosity, moisture, and fertility are crucial for colony establishment of leaf-cutting ants (Della Lucia et al., 1987; Diehl-Fleig \& Rocha, 1998; Soper et al., 2019). However, soil propriety may represent a determinant factor in the composition of these ant communities (Kaspari \& Weiser, 2007; Grześ et al., 2015) since campo sujo and campo limpo environments were characterized by the presence of undeveloped rocky soils (lithosols), preserving sparse shrubs and grassy vegetation.

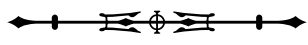




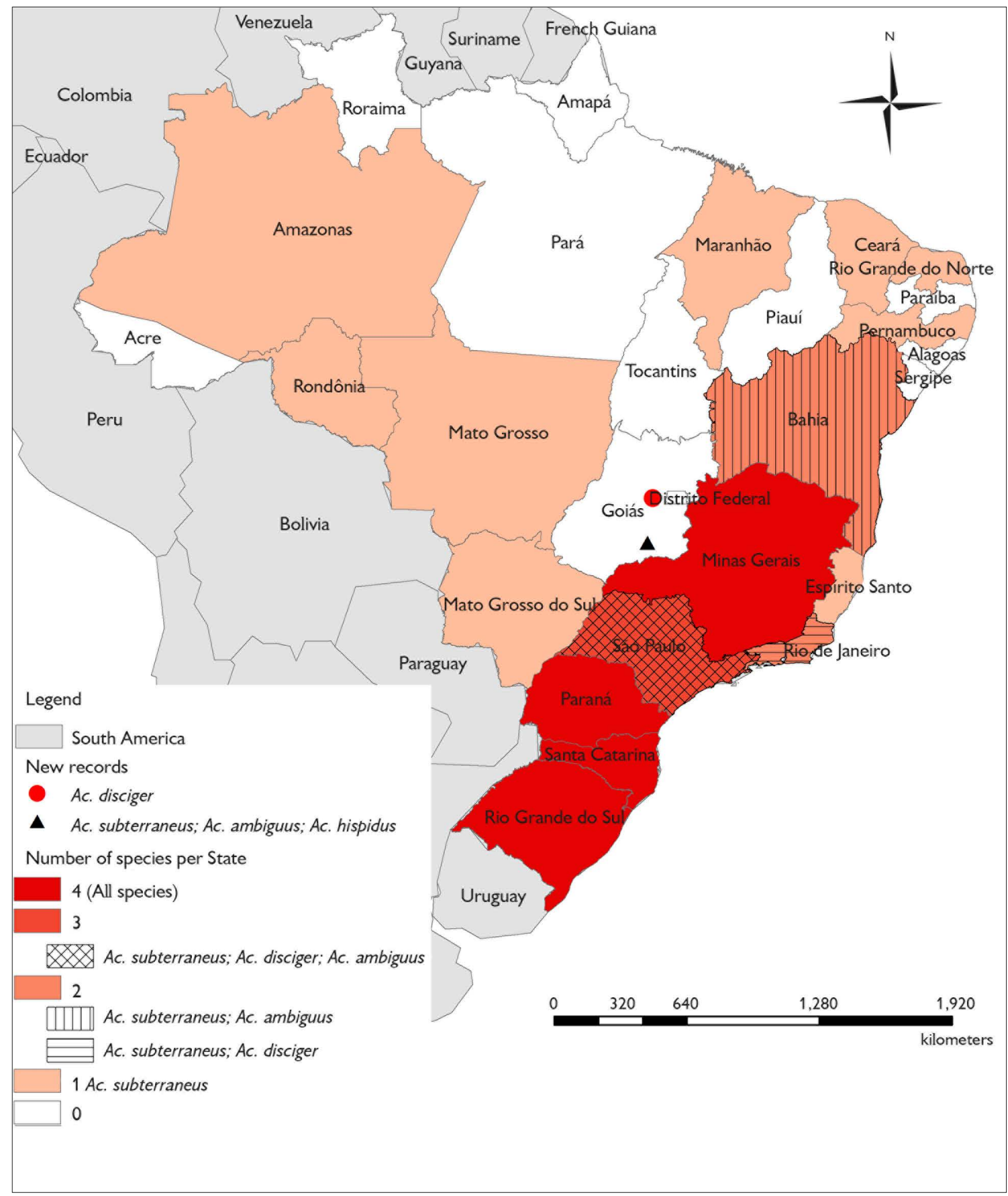

Figure 1. Distribution map of four Acromyrmex species in the Brazilian States, with new records for the State of Goiás, Brazil. Map: Micael Rosa Parreira (2020).

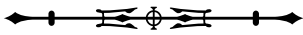


Table 1. Leaf-cutting ants found in native and monoculture environments in three municipalities of the State of Goiás, Brazil. Area in hectare and density in colonies/hectares.

\begin{tabular}{|c|c|c|c|c|c|}
\hline Municipalities & Environment & Coordinates & Area & Density & Taxon \\
\hline Morrinhos & Soybean & $\begin{array}{c}17^{\circ} 44^{\prime} 11.9^{\prime \prime} \mathrm{S} 49^{\circ} \\
03^{\prime} 54.0^{\prime \prime} \mathrm{W}\end{array}$ & 54.46 & $28(0.51)$ & $\begin{array}{c}\text { Atta sexdens sexdens } \\
\text { Atta laevigata }\end{array}$ \\
\hline Silvânia & Pasture & $\begin{array}{c}16^{\circ} 36^{\prime} 27.4^{\prime \prime} \mathrm{S} 48^{\circ} \\
47^{\prime} 41.8^{\prime \prime} \mathrm{W}\end{array}$ & 20.70 & $7(0.34)$ & Atta laevigata \\
\hline Morrinhos & Pasture & $\begin{array}{c}17^{\circ} 49^{\prime} 21.7^{\prime \prime} \mathrm{S} 48^{\circ} \\
53^{\prime} 20.5^{\prime \prime} \mathrm{W}\end{array}$ & 24.27 & $9(0.37)$ & Atta sexdens \\
\hline Morrinhos & Eucalyptus & $\begin{array}{c}17^{\circ} 45^{\prime} 54.3^{\prime \prime} \mathrm{S} 49^{\circ} \\
04^{\prime} 49.4^{\prime \prime} \mathrm{W}\end{array}$ & 46.41 & $23(0.49)$ & $\begin{array}{c}\text { Atta sexdens sexdens } \\
\text { Atta laevigata }\end{array}$ \\
\hline Pirenópolis & Campo sujo & $\begin{array}{c}15^{\circ} 47^{\prime} 22.7^{\prime \prime} \mathrm{S} 48^{\circ} \\
49^{\prime} 58.5^{\prime \prime} \mathrm{W}\end{array}$ & 09.55 & $9(0.94)$ & Acromyrmex disciger \\
\hline Silvânia & Campo limpo & $\begin{array}{c}16^{\circ} 38^{\prime} 27.7^{\prime \prime} \mathrm{S} 48^{\circ} \\
39^{\prime} 26.9^{\prime \prime} \mathrm{W}\end{array}$ & 13.66 & $6(0.44)$ & $\begin{array}{c}\text { Atta sexdens sexdens } \\
\text { Atta laevigata }\end{array}$ \\
\hline Silvânia & Riparian forest & $\begin{array}{c}16^{\circ} 37^{\prime} 51.3^{\prime \prime} \mathrm{S} 48^{\circ} \\
39^{\prime} 52.8^{\prime \prime} \mathrm{W}\end{array}$ & 24.99 & $5(0.20)$ & Atta sexdens rubropilosa \\
\hline Morrinhos & Riparian forest & $\begin{array}{c}17^{\circ} 43^{\prime} 30.7^{\prime \prime} \mathrm{S} 49^{\circ} \\
07^{\prime} 47.0^{\prime \prime} \mathrm{W}\end{array}$ & 43.56 & $34(0.78)$ & $\begin{array}{c}\text { Atta sexdens sexdens } \\
\text { Atta laevigata } \\
\text { Acromyrmex subterraneus } \\
\text { Acromyrmex ambiguus } \\
\text { Acromyrmex hispidus }\end{array}$ \\
\hline
\end{tabular}

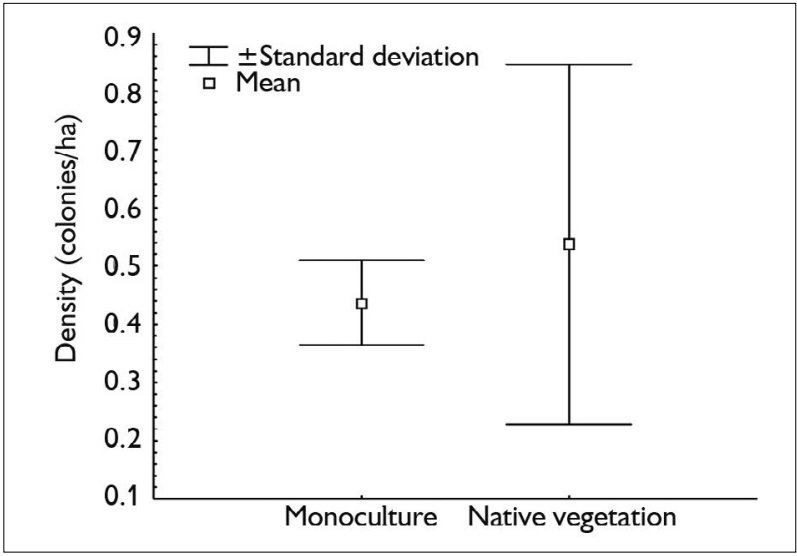

Figure 2. Average density of leaf-cutting ant colonies in native vegetation (open Cerrado and riparian forest) and monoculture (eucalyptus, soybean, and pasture) environments.

The colonies of Ac. disciger in campo sujo, constructed with surface foliage fragments, indicate an adaptation to this type of environmental pressure. The colonies of Atta species that occurred in the pastures were restricted to the edges, close to riparian forests or dense Cerrado woodlands, where we found several foraging trails. This study expands the distribution of
Ac. subterraneus, Ac. disciger, Ac. hispidus, and Ac. ambiguus to the State of Goiás and compare the leaf-cutting ants of genera Atta and Acromyrmex in different environments, demonstrating the great importance of species survey studies.

\section{ACNOWLEDGEMENTS}

We thank the Secretaria de Agricultura e Meio Ambiente de Morrinhos and Instituto Brasileiro do Meio Ambiente e dos Recursos Naturais Renováveis (IBAMA) for permission to survey protected areas. We also thank the Conselho Nacional de Desenvolvimento Científico e Tecnológico (CNPq) for a graduate research scholarship. We thank Micael Parreira and Pedro Borges for helping with the map. We also thank the reviewers for their contributions.

\section{REFERENCES}

ANTMAPS, 2020. Species range maps. Available from: http:// antmaps.org. Accessed on: Feb. 19, 2020.

ANTWEB, 2020. AntWeb v8.14.2. Available from: http://www. antweb.org. Accessed on: Feb. 19, 2020.

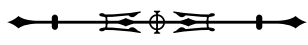


BARRERA, C. A., E. L. BECKER, L. ELIZALDE \& J. M. QUEIROZ, 2017. Parasitoid phorid flies of leaf-cutting ants are negatively affected by loss of forest cover. Entomologia Experimentalis et Applicata 164(1): 66-77. DOI: https://doi.org/10.1111/eea.12593.

DELABIE, J. H. C., H. S. R. ALVES, G. M. REUSS-STRENZEL, A. F. R. CARMO \& I. C. NASCIMENTO, 2011. Distribuição das formigascortadeiras dos gêneros Acromyrmex e Atta no Novo Mundo. In: T. M. C. DELLA LUCIA (Ed.): Formigas-cortadeiras: da biologia ao manejo: 87-89. Editora Folha de Viçosa, Viçosa.

DELLA LUCIA, T. M. C., 2003. Hormigas de importancia económica en la región Neotropical. In: F. FERNÁNDEZ (Ed.): Introducción a las hormigas de la región Neotropical: 342-349. Instituto de Investigación de Recursos Biológicos Alexander von Humboldt, Bogotá.

DELLA LUCIA, T. M. C., E. F. VILELA \& D. D. O. MOREIRA, 1987. Criando saúvas em laboratório. Ciência Hoje 6(35): 28-29.

DIEHL-FLEIG, E. \& E. S. ROCHA, 1998. Escolha do solo por fêmeas de Acromyrmex striatus (Roger) (Hymenoptera: Formicidae) para construção de ninho. Anais da Sociedade Entomológica do Brasil 27(1): 41-45. DOI: https://doi.org/10.1590/S030180591998000100005 .

FOWLER, H. G., 1983. Distribution patterns of paraguayan leafcutting ants (Atta and Acromyrmex) (Formicidae: Attine). Studies on Neotropical Fauna and Environment 18(3): 121-138. DOI: https:// doi.org/10.1080/01650528309360626.

FOWLER, H. G., T. M. C. DELLA-LUCIA \& D. D. O. MOREIRA, 1993. Posição taxonômica das formigas cortadeiras. In: T. M. C. DELLA LUCIA (Ed.): As formigas cortadeiras: 4-25. Editora Folha de Viçosa, Viçosa.

GRZEŚ, I. M., M. OKRUTNIAK \& M. WOCH, 2015. Monomorphic ants undergo within-colony morphological changes along the metalpollution gradient. Environmental Science and Pollution Research 22(8): 6126-6134. DOI: https://doi.org/10.1007/s11356-014-3808-5.

HÖLLDOBLER, B. \& E. O. WILSON, 1990. The ants: 1-746. Belknap Press, Cambridge.

KASPARI, M. \& M. WEISER, 2007. The size-grain hypothesis: do macroarthropods see a fractal world? Ecological Entomology 32(3): 279-282. DOI: https://doi.org/10.1111/J.1365-2311.2007.00870.x.

OliVEIRA, M. A., M. S. ARAÚJO, G. C. MARINHO, M. M. R. RIBEIRO \& T. M. C. DELLA LUCIA, 2011. Manejo de formigascortadeiras. In: T. M. C. DELLA LUCIA (Ed.): Formigas-cortadeiras: da biologia ao manejo: 400-419. Editora Folha de Viçosa, Viçosa.
OLIVEIRA-FILHO, A. T. \& J. A. RATTER, 2002. Vegetation physiognomies and wood flora of the Cerrado biome. In: P. S. OLIVEIRA \& R. J. MARQUIS (Ed.): The cerrados of Brazil: ecology and natural history of a neotropical savanna: 91-120. Columbia University, New York.

PESQUERO, M. A., L. A. BESSA, H. C. M. SILVA, L. C. SILVA \& F. V. ARRUDA, 2010. Influência ambiental na taxa de parasitismo (Diptera: Phoridae) de Atta laevigata e Atta sexdens (Hymenoptera: Formicidae). Revista de Biologia Neotropical 7(2): 35-38.

RANDO, J. S. S. \& L. C. FORTI, 2005. Ocorrência de formigas Acromyrmex Mayr, 1865, em alguns municípios do Brasil. Acta Scientiarum. Biological Sciences 27(2): 129-133. DOI: https://doi. org/10.4025/actascibiolsci.v27i2.1322.

RAO, M., 2000. Variation in leaf-cutter ant (Atta sp.) densities in forest isolates: the potential role of prediction. Journal of Tropical Ecology 16(2): 209-225. DOI: https://doi.org/10.1017/S026646740000136X.

SANTOS, I. C. L., A. SANTOS, Z. OUMAR, M. A. SOARES, J. C. C. SILVA, R. ZANETTI \& J. C. ZANUNCIO, 2019. Remote sensing to detect nests of the leaf-cutting ant Atta sexdens (Hymenoptera: Formicidae) in teak plantations. Remote Sensing 11(14): 1-12. DOI: https://doi.org/10.3390/rs11141641.

SOPER, F. M., B. W. SULLIVAN, B. B. OSBORNE, A. N. SHAW, L. PHILIPPOT \& C. C. CLEVELAND, 2019. Leaf-cutter ants engineer large nitrous oxide hot spots in tropical forests. Proceedings of the Royal Society B: Biological Sciences 286(1894): 20182504. DOI: https://doi.org/10.1098/rspb.2018.2504.

VASCONCELOS, H. L. \& J. M. CHERRETT, 1995. Changes in leaft cutting ants population (Formicidae: Attini) after the clearing of mature forest in Brazilian Amazonia. Studies on Neotropical Fauna and Environment 30(2): 107-113. DOI: https://doi. org/10.1080/01650529509360947.

VASCONCELOS, H. L., E. H. M. VIEIRA-NETO, F. M. MUNDIM \& E. M. BRUNA, 2006. Roads alter the colonization dynamics of a keystone herbivore in Neotropical Savannas. Biotropica 38(5): 661-665. DOI: https://doi.org/10.1111//.1744-7429.2006.00180.x.

ZANETTI, R., K. JAFFÉ, E. F. VILELA, J. C. ZANUNCIO \& H. G. LEITE, 2000. Efeito da densidade e do tamanho de sauveiros sobre a produção de madeira em eucaliptais. Anais da Sociedade Entomológica do Brasil 29(1): 105-112. DOI: https://doi. org/10.1590/S0301-80592000000100013. 
